\title{
ThE Papers
}

Dpto. Teoría e Historia Económica Universidad de Granada

\author{
Working Paper n. 18/ 03
}

The Fiscal and Welfare

Consequences of the Price Indexation of Spanish Pensions

Julian Díaz Saavedra June 10, 2018 


\title{
The Fiscal and Welfare Consequences of the Price Indexation of Spanish Pensions*
}

\author{
Julián Díaz-Saavedra \\ Universidad de Granada \\ $<$ julianalbertodiaz@ugr.es $>$
}

May 23rd, 2018

\begin{abstract}
The 2013 Spanish Pension Reform, aimed at guaranteeing the financial sustainability of the system, introduced, among other measures, the Pension Revaluation Index (PRI), which uncouples annual pension updates from the Consumer Price Index (CPI) increases and makes the annual rise in all pensions conditional upon the system's revenue and expenditure being balanced, with ceilings and floors set in place. This automatic adjustment mechanism, however, has posed serious concerns about future pension adequacy, this being the degree of poverty alleviation and consumption smoothing that the pensions system provides to retirees, due to the expected large future reductions in the real value of the average pension. In this paper, we use a general equilibrium life cycle model, calibrated to micro and macro data in Spain, to study the fiscal and welfare consequences of three options for increasing pension generosity in Spain: (i) disability and minimum pensions are again fully indexed with the CPI; (ii) minimum and lower value pensions are fully indexed with the CPI; and (iii) returning to full price indexation of all Spanish pensions. While these three reforms increase, on average, pension adequacy, the tax increases needed to finance the higher future pension expenditure differ significantly. Moreover, most current cohorts prefer returning to the full price indexation of all Spanish pensions, but future cohorts prefer that only disability and minimum pensions be fully indexed with the CPI.
\end{abstract}

Keywords: Computable general equilibrium, social security reform, retirement

JEL classification: C68, H55, J26

\footnotetext{
${ }^{*}$ This paper has benefited greatly from the insights and advice of Javier Díaz-Giménez. I thank Juan Carlos Conesa for an early version of the code. I am also grateful to the editor and to two anonymous referees for valuable suggestions and comments.
} 


\section{Introduction}

In the last few decades, EU countries have implemented a series of pension reforms aimed at reducing public spending on pensions in order to guarantee their future sustainability in view of rising demographic dependency rates. Moreover, the economic recession faced by Europe in recent years has prompted an intensification of these pension reforms in many countries, through the adoption of additional parametric, or even structural, changes, sometimes with short-term impacts.

These sustainability-enhancing reforms have been designed with different measures that have modified retirement rules and parameters ${ }^{1}$. For instance, Finland, France, the Netherlands and Spain introduced different actions in order to change the retirement incentives, such as making the pathways to early retirement harder, or increasing the number of years of contributions needed to collect a full retirement pension. Spain has also, along with other European countries such as Belgium and Germany, started to gradually increase legal retirement ages. Reducing relative pension benefits is another set of measures aimed at reducing the generosity of the pension system, by which countries like Greece, Finland and France have modified, for example, the number of years and valorization of pensionable earnings, or the calculation of pensions at retirement. Finally, other countries have implemented measures to increase revenues, such as Denmark, France, Portugal and the UK, which have increased social contribution rates.

On the other hand, several European countries have implemented structural reforms. Among these structural changes, it is worth mentioning the introduction of new pillars and/or changing the nature of the public pension systems. For example, Italy, Latvia, Poland and Sweden have converted their Defined Benefit public pillar to a Notional Defined Contributions system, while other European countries have introduced mandatory private accounts. Thus, while countries like Bulgaria, Estonia and Croatia have implemented individual private schemes, Cyprus and Slovenia introduced mandatory private occupational accounts, where, in most cases, contributions to the new private pension accounts were financed through shifting part of the payroll taxes raised for the public pension system ${ }^{2}$.

However, another important element in the aforesaid process of pension reform is the introduction of automatic adjustment mechanisms, aimed at automatically adjusting the main pension system parameters to changes in demographics. Of these mechanisms, three were the most commonly implemented: automatic balancing mechanisms, sustainability factors, and retirement ages linked to life expectancy. Nevertheless, more than half of the countries in the European Union have yet to introduce any of these automatic mechanisms. Italy, in 1995, was the first country to legislate on the introduction of an automatic adjustment that increases the legal retirement ages

\footnotetext{
${ }^{1}$ See Carone et al. (2018) for a complete survey about pension reform in Europe.

${ }^{2}$ See Chłoń-Domińczak (2018).
} 
according with future gains in life expectancy. Since then, several other countries, like Denmark in 2011 or the Netherlands in 2012, have decided to introduce such an adjustment mechanism ${ }^{3}$. As with changes in retirement ages, sustainability factors have also been introduced by several countries (Italy, France and Sweden being examples), where these factors change the amount of the initial pension benefit according to demographic changes, mainly changes in life expectancy at the time of retirement.

Finally, automatic balancing mechanisms guarantee that the pension system will be financially sustainable during the coming decades by adjusting benefit indexation. Until now, this balancing mechanism has only existed in three countries. In Germany, benefit indexation is reduced through a contribution rate factor and a sustainability factor. In Sweden, this mechanism reduces benefit indexation in the event that the public pension system faces a deficit in the medium term. And in Spain (see below), there is a reduced benefit indexation when there is a present or expected deficit in the public pension scheme. Lastly, it is also worth mentioning that only five European countries have introduced two automatic adjustment mechanisms simultaneously. Specifically, Italy, Portugal and Finland have retirement ages linked both to life expectancy and sustainability factors, while Spain and Sweden have sustainability factors and automatic balancing mechanisms.

The aforementioned pension reforms will have an important impact on containing future pension expenditure trends. Specifically, the average pension benefit to average wage ratio will decline significantly in most EU countries, so that the public pension expenditure as a share of GDP would be no higher in 2060 than at present for the EU28 as a whole ${ }^{4}$. But note that the role of pension systems is basically twofold: income allocation over the life cycle and poverty protection at older ages. Consequently, these estimates indicate that these reforms may have adverse consequences for future pension adequacy, so that these parametric and structural changes may also contribute to reducing the poverty alleviation role of the public pension systems (see Grech 2015). Therefore, the main obstacles to future pension adequacy coming from these reforms are those that proceed from the decrease in the relative value of pension benefits, and this is due both to a weaker valorization and indexing. Additionally, those pension reforms aimed at ensuring financial sustainability merely by lowering retirement benefits, aside from making it difficult to provide protection against poverty, heighten the risk of policy reversals. Put differently, if pension reforms imply an increasing number of people without acceptable incomes, the future sustainability of public pension systems may also be eroded by the risk of policy reversals.

As stated earlier, in the last few years Spain has also undertaken two major pension reforms. The 2011 and 2013 Spanish pension system reforms addressed the demographic challenge by, among other measures, increasing the legal retirement ages and introducing a Sustainability Factor linking

\footnotetext{
${ }^{3}$ Eight European countries have linked retirement ages to life expectancy. See again Carone et al. (2016).

${ }^{4}$ This is the case for countries such as Belgium, Denmark, Estonia and Spain. See the Aging Working Group from the European Commission (2015) for a quantitative analysis.
} 
the initial pension to the increase in life expectancy ${ }^{5}$. Furthermore, the 2013 Pension Reform has introduced an automatic adjustment mechanism, the Pension Revaluation Index (PRI), which uncouples annual pension updates from the Consumer Price Index (CPI) increases, which had previously been linked, but sets the annual increase in pensions on the basis of a formula derived from the balance between the system's revenue and expenditure, although such revaluation cannot be lower than 0.25 nor higher than the sum of 0.5 to the CPI increase.

Some previous research papers have studied the quantitative effects of these pension reforms (see, for example, Díaz-Giménez and Díaz-Saavedra (2017), Hernández de Cos et al. (2017), Patxot et al. (2017), Sánchez-Martín (2017), and De la Fuente et al. (2018)), and they all conclude that these reforms substantially improve the sustainability of Spanish pensions, and that they limit the tax increases that would have been necessary to finance the pension system deficits ${ }^{6}$. The key mechanism from the viewpoint of making headway in the sustainability of the system is the PRI, since it severely limits the growth rate of pensions, so that large reductions in the generosity of public pensions for current and future generations of retirees are expected. For instance, DíazGiménez and Díaz-Saavedra (2017) find that these reforms will reduce the real value of the average pension by about 33 percent by 2050 , when compared to the values that would have obtained without the reforms.

The projected reduction of the real value of Spanish pensions, however, is so large that it is hard to believe that it will be politically sustainable, even in the near future. Put differently, since these reforms could leave an increasing number of people without adequate incomes, the future sustainability of the Spanish public system may also be affected by the risk of policy reversals. In fact, since the introduction of this adjustment mechanism, the annual nominal revaluation of the pensions in force since 2014 has been 0.25 percent, but the inflation rate increased from 1.1 percent in 2014 to 1.2 percent in 2017. This loss in the purchasing power of pensions, along with the losses projected for the coming decades, has therefore caused growing concern in public opinion. Moreover, the main opposition parties as well as the two main trade union federations have demanded that the Spanish government repeal the PRI and that the pensions in effect be newly revalued with the CPI in order to maintain their purchasing power ${ }^{7}$.

The risk of policy reversal is also increased because the Spanish pension reforms were not accompanied by other retirement incomes or safety nets to prevent the elderly from falling into poverty. Specifically, a minimum pension or other forms of guarantees could serve as poverty protection in

\footnotetext{
${ }^{5}$ The 2011 Spanish Pension reform has also extended the period over which earnings are taken into account for the calculation of the first pension. This measure has the effect of reducing pension benefits, given the normal upward slope to the age-earnings profile for most workers.

${ }^{6}$ Other previous papers have studied the quantitative effects of the Spanish 2011 Pension Reform, which introduced gradual changes both in the regulatory base and in the legal retirement ages, but which did not enact either the Sustainability Factor or the Pension Revaluation Index. Three examples are De la Fuente and Domenech (2013), Conde-Ruiz and Gonz ález (2013) and Moral-Arce (2013).

${ }^{7}$ The Spanish government announced in April of 2018 that it was going to temporarily skip the PRI, and that all Spanish pensions will be revaluated with the CPI both in 2018 and 2019.
} 
old age, so that, and as is generally advocated, the evolution of this minimum guaranteed level can be observed to see whether it continues to serve its protective purpose ${ }^{8}$. But, and until now, this is not the case in Spain, since the Pension Revaluation Index (PRI), approved in the 2013 reform, establishes that the minimum pension has to evolve according to the rest of contributory pensions and therefore will be almost constant in nominal terms in the long run (i.e. a $0.25 \%$ increase in nominal terms per year). Thus, a change in the revaluation rules for those lower value pensions could both allow the pension system to continue fulfilling its role as poverty protection at older ages and also help to reduce the risk of policy reversal of the aforementioned pension reforms.

In this paper we therefore analyse the fiscal, aggregate and welfare consequences of returning to full CPI indexation for part or all of the Spanish public pensions in 2018. To this end, we simulate and compare four model economies. In the first model economy, which we label Model Economy Ben, we simulate the 2011 and 2013 pension system reforms and we use the PRI to revaluate every pension in payment. In all the other model economies, we also replicate the 2011 and 2013 Spanish pension system reforms but we eliminate the Pension Revaluation Index on part or all of Spanish pensions. Specifically, in the second model economy, which we label Model Economy Re1, we assume that only disability and minimum pensions are fully indexed with the CPI. In the third model economy, which we label Model Economy Re2, we assume that both the minimum pension and all pensions below 40 percent of per capita GDP are fully indexed with the CPI. Finally, in the fourth model economy, which we label Model Economy Re3, we assume the full CPI indexation of all Spanish public pensions.

To do this, we use a life-cycle general equilibrium model of labour supply and retirement, where ex-ante educationally heterogeneous workers face idiosyncratic labour income risk. Our model economy is an enhanced version of the general equilibrium, multi-period, overlapping generations model economy populated by heterogeneous households described in Díaz-Giménez and Díaz-Saavedra (2017). The main features of this model economy are the following: the households differ in age, education and employment status, and, consequently, in income, wealth, pension rights, and pensions, and they decide optimally how much to work, consume, and save and when to retire. Production is carried out by a neoclassical representative firm that behaves competitively in its product and factor markets. We also model a government that runs a fully explicit and detailed pay-as-you-go pension system financed with payroll taxes, and which uses consumption, capital and income taxes to finance exogenous sequences of government expenditure and public transfers other than pensions. Finally, we also assume that the consumption tax rate increases as needed to finance the pension system deficit once the Pension Reserve Fund runs out.

However, the model economy that we study here differs from the one that we used in that article

\footnotetext{
${ }^{8}$ For example, the need to provide an adequate minimum income is asserted by the International Labour Organization (ILO) and the World Bank. According to these organizations, the minimum pension should not be lower than 40 percent of average earnings. See Holzmann and Hinz (2005) and Humblet and Silva (2002).
} 
in an important way. We have introduced unemployment as an additional labour status, where unemployment is stochastic and the unemployment risk is age-dependent. Thus, in our model economy, unemployed households also differ in their age, education, asset holdings and pension rights; they receive unemployment benefits from the government, and they face a survival shock and an employment shock. We also assume that the decision to return to employment, once a job offer is received, is exogenous and mandatory. They also decide endogenously how much to consume and save, and once they reach the first retirement age, they are forced to retire.

The introduction of unemployment risk is important not only because the Spanish unemployment rate remains stubbornly high at 16.7 percent, affecting thus the effective old-age dependency ratio, but also because the introduction of unemployment risk has required us to change the calibration of our model economy ${ }^{9}$. Specifically, we recalibrated our model economy so that it could continue to replicate as closely as possible selected macroeconomic aggregates and ratios, distributional statistics and the institutional details of Spain. This process also entailed some changes in the results in comparison to those reported in the previous version.

Among the most important changes made in the parameterization of the model, three stand out. First, this version of the model introduces a lower value for the discount factor, $\beta$, used to match the empirical capital to output ratio, since this Spanish ratio has decreased during the recent economic recession ${ }^{10}$. Second, we also recalibrated the stochastic component of the endowment of efficiency labour units process so that the model continues to match Spanish earnings inequality. As an additional result, the invariant distribution that results from this recalibration shows a larger concentration of workers in the lowest earnings productivity shock, so that an average worker is somehow less productive in this version of the model in comparison to that same worker in DíazGiménez and Díaz-Saavedra (2017). Finally, this version of the model economy assumes a lower labour augmenting growth rate scenario for the coming decades ${ }^{11}$.

These differences are important, particularly for the retirement decision. Specifically, a lower weight attached to consumption when old, and a lower total average productivity at older ages, induce workers, everything being equal, to shorten their working lifetime. This in turn mainly affects the growth rate in the number of pensions, a key variable to determine the PRI. On the other hand, the new growth scenario also affects the PRI, as it tracks payroll tax growth, and payroll tax growth tracks earnings growth. Consequently, the final outcome is a lower projected PRI during the coming decades in this version of our model economy, in comparison to our previous estimates. Besides this, the new endogenous sequence of the PRI is now more in line with those sequences obtained by other research papers that also study the latest reforms of the Spanish

\footnotetext{
${ }^{9}$ The effective old-age dependency ratio is defined here as the ratio of number of pensions to number of workers. ${ }^{10}$ See the Instituto Valenciano de Investigaciones Económicas (Ivie).

${ }^{11}$ Specifically, this rate is 1.5 percent from 2022 onwards rather than 1.9 percent, as was the case in Díaz-Giménez and Díaz-Saavedra (2017), the rationale for this choice being because the Spanish average annual labour productivity growth rate between 1980 and 2012 was precisely 1.5 percent, according to the OECD.
} 
pension system (see for example Sánchez-Martín (2014), and De la Fuente et al. (2018)).

The findings of this paper are fourfold. First, the aforesaid reforms improve the generosity of the pension system, since the average pension increases progressively, and by 2070 is 13, 20, and 52 percent higher in real terms. Thus, the reforms contribute to preventing old-age poverty and at the same time provide a means to smooth lifetime consumption. But this higher generosity is achieved at the expense of increasing pension expenditure, and consequently, pension deficits. On average, yearly pension expenditure increases by $0.6,1.5$, and 3.5 percentage points of output during the ensuing decades. On the revenue side, if the government resorts to indirect taxes, which is also the preferred option among experts proposing alternatives for reforming the Spanish Tax System, the consumption tax rate should be increased on average by 7,12 , and 30 percent. Thus, the return to a price indexation rule of part or all of Spanish pensions essentially implies trading off higher pensions against the higher consumption tax rates that are needed to finance them.

Second, the optimal response of households to this trade-off is to save and work fewer hours in the reformed Model Economies Re2 and Re3. Higher pensions reduce saving rates since they decrease the optimal level of assets needed to support consumption when retired, and labour input also decreases as the higher taxes reduce the average time allocated to market activities. Consequently, both reforms make the growth rates of output smaller; this reduction is progressive and, by 2070, output is 5 and 7 percent lower in comparison to the benchmark Model Economy Ben. However, this is not the case in the reformed Model Economy Re1, because the lower saving rates are compensated by the longer working lifetime, as workers optimally decide to delay retirement since disability risk is covered by more generous disability pensions. Thus, we find that there is no significant variation in output in comparison to the benchmark model that same year.

Third, we find that most of the households alive at the time these pension reforms start to be implemented prefer the return to a price indexation rule of all Spanish pensions, since this indexation rule brings about sizeable aggregate welfare gains equivalent to 2.9 percent of aggregate consumption that same year. On the other hand, newborns are better off if both minimum and disability pensions are indexed to CPI, where the individual welfare gains of future cohorts increase until 3.0 percent of consumption for cohorts born in 2050. That is, future cohorts prefer to pay higher consumption taxes if these additional tax collections are used to increase those pensions aimed at protecting against poverty and disability risk. And fourth, the first two reforms reduce pension inequality during the ensuing decades, since both reforms keep the real value of the minimum pension constant, while they both continue to revaluate the maximum pension with the PRI. Put differently, if these reforms were maintained indefinitely, there would be a point in time where the value of both the minimum and the maximum pension would be equal. On the other hand, the full price indexation of all Spanish pensions increases pension inequality, in comparison with the current system in Spain. 
The paper is organized as follows: section 2 describes the Spanish pay-as-you-go pension system; section 3 presents the model economy; section 4 describes the calibration procedure; section 5 describes the simulations; section 6 presents the results; section 7 quantifies the welfare consequences; section 8 discusses the robustness of our results; and, lastly, section 9 concludes.

\section{The Spanish Social Security}

The Spanish contributory pension system, is the most important program of social protection in Spain, where public contributory pensions are provided by the following three programs. First, the Régimen General de la Seguridad Social covers the private sector employees and the members of cooperative firms and the employees of most public administrations other than the central governments. Second, the Regímenes Especiales de la Seguridad Social cover the self-employed workers and professionals ${ }^{12}$. And third, the scheme for government employees, or Régimen de Clases Pasivas covers public servants employed by the central government and its local branches.

In this article we focus exclusively on the retirement and disability pensions payed by the Régimen General de la Seguridad Social. Consequently, this section describes the key features of this system and its 2011 and 2013 reforms.

Financing and elegibility. The Régimen General de la Seguridad Social is a mandatory pay-asyou-go scheme. The payroll tax rate is proportional to covered earnings, which are defined as total earnings, excluding payments for overtime work, between a floor and a ceiling that vary by broadly defined professional categories. The payroll tax rate is 28.3 percent, of which 23.6 percent is attributed to the employer and the remaining 4.7 percent to the employee.

Entitlement to an old-age pension requires at least 15 years of contributions. The retirement age that entitles workers to receive a full retirement pension is 65 for workers who have contributed at least 36 years and three months. Previous to the 2011 Pension reform, every worker aged 61 or older could retire earlier paying an early retirement penalty, as long as they had contributed to the pension system for at least 30 years. Exceptionally, workers who had entered the system before 1967 could retire at age 60 . The 2011 Reform of the Spanish pension system delayed the early retirement age from 61 to 63 for those workers who decide to retire on a voluntary basis, and it also delayed the full entitlement retirement age from 65 to 67 . The delay in the early retirement age was immediate, and the delays in the normal retirement are gradual: one month per year between 2013 and 2018, and two months per year between 2019 and 2027. Consequently, the full entitlement retirement age in Spain will be 66 in 2021 and 67 in 2027.

\footnotetext{
${ }^{12}$ This program includes self-employed, agricultural workers and small farmers, domestic workers, sailors, and coal miners.
} 
Retirement Pensions. The main component of the retirement pension is the Regulatory Base, defined as the average covered earnings of the last 20 years before retirement. Labor income earned in the last two years prior to retirement enters the calculation in nominal terms, and the covered earnings of the remaining years are revaluated using the rate of change of the Spanish Consumer Price Index. The 2011 Reform of the Spanish pension system extended the number of years of earnings used by the Regulatory Base up to the last 25 years before retirement. The extension of the number of years used to compute the pensions was phased in gradually and it will end in 2022. In addition, the Regulatory Base in multiply by a percentage which depends on the age of the retirees and on the number of years of contributions. And, each year worked after the full entitlement retirement age increases the Regulatory Base in 2 or 3 percentage points depending on the length of the contributory career. Finally, retirement pensions are bound by a minimum and a maximum pension, where minimum pensions depend the pensioner's age and on the composition of the household.

The 2013 Reform of the Spanish pension system introduced a Sustainability Factor whose purpose is to adjust the pensions with the life-expectancy at retirement so that the life-time cost of retirement is approximately the same for every cohort. The Sustainability Factor only affects new pensioners joining the system in 2019 onwards.

Disability pensions. The Spanish pension system rules define pensionable income for workers who qualify for a disability pension as the average covered earnings of the previous 15 years, for workers who are younger than 52 , or of the previous 8 years, for workers who are 52 or older, and the standard disability pension is 75 percent of the pensionable income when the disability is due to an occupational accident or illness. But if the worker is covered by a collective agreement, this percentage can reach the $100 \%$ of that amount. Additionally, there are other situations in which disability pensions are only $50 \%$ of the pensionable income.

The Revaluation of pensions. In 2014, the Spanish pension system moved from a full price indexation of pensions to a partial price indexation achieved updating pensions with a Pension Revaluation Index. This index sets the annual increase in pensions on the basis of a formula derived from the balance between the system's revenue and expenditure, although such revaluation cannot be lower than $0.25 \%$ nor higher than the sum of $0.5 \%$ to the Consumer Price Index increase.

The Pension Reserve Fund. Since 2000, part of the surpluses generated by the pension system are deposited in a Pension Reserve Fund. The assets accumulated in this fund have been then used to finance the pension system deficits, and at the end of 2016, the total amount of assets accumulated in the pension reserve fund was 15,020.04 million euros which corresponded to 1.34 percent of that year's GDP. 


\section{The Model Economy}

We study an overlapping generations model economy with heterogeneous households, a representative firm, and a government. Our model economy is an enhancement of the model economy described in Díaz-Giménez and Díaz-Saavedra (2017). For the sake of brevity, we offer only a brief summary of its main features here. A detailed description of this model economy can be found in the technical appendix to this paper that is available at http://www.ugr.es/ julianalbertodiaz/research/ PEN65-APP-K21.pdf.

\subsection{The Households}

Age and Education: The economy is populated by overlapping generations of heterogeneous households of age $j=20,21, \ldots, 100$. Each period the households face an age-dependent and time-varying conditional probability of surviving from age $j$ to age $j+1$, which we denote by $\psi_{j t}$. The households can be either high school dropouts, high school graduates, or college graduates. This educational level, which we denote by $h$, is exogenous and it is determined forever when they enter the economy.

Labour Status and Endowments: Households in our model economy are either workers, unemployed, disabled households, or retirees. Every household enters the economy as a worker and with no assets. Workers receive an endowment of efficiency labor units every period. This endowment has two components: a deterministic component, which we denote by $\epsilon_{j h}$, and a stochastic, idiosyncratic component, which we denote by $s$. The deterministic component depends on the household age and education, and we use it to represent the life-cycle profiles of earnings. The stochastic component is independent and identically distributed across households, it follows a first order, finite state Markov chain, and we use it to generate earnings and wealth inequality within the age cohorts. The labor income of workers is $y_{t}^{l}=\epsilon_{j h} \times s \times w \times l$, where $w$ is the market wage and $l$ is the time devoted to working in the market, which is endogenous.

Workers of age $j$ at period $t$ face a probability $p_{v j t}$ of becoming unemployed from age $j+1$ onwards. The unemployment shock is temporary, and it is realized at the end of each period, once workers have made all their labor and consumption decisions. When a worker becomes unemployed, she receives unemployment benefits from the government, and she decides endogenously how much to consume and save. And once that she reaches the first retirement age, $R_{0}$, she is forced to retire.

The decision to return to employment is exogenous and mandatory. Unemployed households of age $j$ at period $t$ receive a job offer with probability $p_{\omega j t}$, and this offer is the productivity shock $s$. Therefore, its amount is either $s_{1}, s_{2}$, or $s_{3}$. Conditional on receiving an offer, the probability of receiving each one of them is the unconditional probability of each realization of that shock. Once 
a household is re-employed, the future values of $\mathrm{s}$ are determined by the process on $s^{13}$.

Workers of age $j$ and educational level $h$ face a probability $\varphi_{j h}$ of becoming disabled from age $j+1$ onwards. The disability shock is realised at the end of each period, once workers have made all their labor and consumption decisions. When a worker becomes disabled, she exits the labour market and receives no further endowments of efficiency labour units, but she is entitled to receive a disability pension until she dies.

Workers of age $R_{0}$ or older observe their realisations of the two components of their endowment of efficiency labor units and their pensions, and they decide whether to remain in the labour force for that period, or whether to retire and start collecting their retirement pension. Both the disability shock and the retirement decision are irreversible and there is no mandatory retirement age.

Preferences: The households order their sequences of consumption and leisure according to a constant relative risk aversion utility function, $u(c, 1-l)$, where $c$ denotes consumption and $1-l$ denotes leisure.

Technical assumptions: We assume that there are no insurance markets for the stochastic component of the endowment shock and that the households cannot borrow. When insurance markets are allowed to operate, every household of the same age and education level is alike and the income and wealth distributions in our model economy become much more disperse.

\subsection{The Representative Firm}

In our model economy there is a representative firm. Aggregate output, $Y_{t}$, is obtained combining aggregate capital, $K_{t}$, with the aggregate labor input, $L_{t}$, through a Cobb-Douglas, aggregate production function which we denote by $Y_{t}=K_{t}^{\theta}\left(A_{t} L_{t}\right)^{1-\theta}$. In this expression, $A_{t}$ is an exogenous labor-augmenting productivity factor whose law of motion is $A_{t+1}=\left(1+\gamma_{t}\right) A_{t}$, and $A_{0}>0$. We assume that factor and product markets are perfectly competitive and that the capital stock depreciates geometrically at a constant rate, which we denote by $\delta$.

\subsection{Government Policy}

The government in our model economy taxes capital income, household income, and consumption, and it confiscates unintentional bequests. It uses its revenues to consume, and to make transfers to households other than pensions. In addition, the government runs a pay-as-you-go pension system.

\footnotetext{
${ }^{13}$ To calibrate unemployment risk, we use the data provided by the Estadística de Flujos de la Población Activa survey from the Spanish Instituto Nacional de Estadística (INE). This survey reports the flows between the different labour status of people divided by age groups, but it does not present these same flows conditioned by the education of individuals. This is the reason why the unemployment risk does not depend on educational level in our model economy.
} 
The consolidated government and pension system budget constraint is

$$
G_{t}+Z_{t}+P_{t}+U_{t}=T_{k t}+T_{y t}+T_{c t}+E_{t}+T_{s t}+\left[F_{t}\left(1+r^{*}\right)-F_{t+1}\right]
$$

In the expenditure side, $G_{t}$ denotes government consumption, $Z_{t}$ denotes government transfers other than pensions, $P_{t}$ denotes pensions, and $U_{t}$ denotes unemployment benefits. And, in the revenue side, $T_{k t}, T_{y t}$, and $T_{c t}$, denote the revenues collected by the capital income tax, the household income tax, and the consumption tax, $E_{t}$ denotes unintentional bequests, $T_{s t}$, denotes the revenues collected by the payroll tax, $F_{t}>0$ denotes the value of the pension reserve fund at the beginning of period $t$, and $r^{*}$ denotes the exogenous interest rate that the government obtains from the pension reserve fund assets. Consequently, $\left[F_{t}\left(1+r^{*}\right)-F_{t+1}\right]$ denotes either the revenues that the government obtains from the pension reserve fund or the funds that it deposits into it. The pension reserve fund must be non-negative, and we assume that $G_{t}$ and $Z_{t}$ are thrown into the sea so that they create no distortions in the household decisions. Finally, we assume that the capital income tax rate is constant, that the household income tax rate is progressive, and that, when the pension reserve fund runs out, the government changes the consumption tax rate as needed in order to finance the pensions.

\subsection{The Pension System}

In our benchmark model economy we choose the payroll tax and the pension system rules so that they replicate as closely as possible the Régimen General de la Seguridad Social of the Spanish payas-you-go pension system ${ }^{14}$. The payroll tax is capped and workers older than the full entitlement retirement age, which we denote by $R_{1}$, are exempt from paying payroll taxes ${ }^{15}$.

Retirement pensions. A household of age $j \geq R_{0}$, that chooses or is forced to retire, receives a retirement pension, $p_{t}$, which we compute following the Spanish pension system rules. The main component of the retirement pension is its Regulatory Base which averages labor earnings up to the maximum covered earnings, during the $N_{b}$ years prior retirement ${ }^{16}$. If a household has not reached the full entitlement retirement age, its pension is subject to an early retirement penalty. If the household is older than $R_{1}$, its pension claims are increased by 3 percent for each year worked after this age. The regulatory base is multiplied by a pension replacement rate which we use to replicate the pension expenditures to output ratio. Finally, retirement pensions are bounded by a minimum and a maximum pension ${ }^{17}$.

\footnotetext{
${ }^{14}$ The Régimen General de la Seguridad Social is the most important pension program in the Spanish Public Pension System.

${ }^{15}$ We assume that unemployed households also pay payroll taxes.

${ }^{16}$ In the case of an unemployed, it is considered as labor earnings the unemployment benefit granted by the government.

${ }^{17}$ Following the 2013 reform to the Spanish pension system, we assume that The Sustainability Factor only affects new pensioners joining the system in 2019 onwards.
} 
Disability pensions. To replicate the current Spanish rules, we assume that there is a minimum disability pension that coincides with the minimum retirement pension, and that the disability pension is 75 percent of the household's regulatory base.

The Revaluation of pensions. Following the 2013 reform to the Spanish pension system, we assume that both retirement and disability pensions are revaluated using the Pension Revaluation Index.

\subsection{Equilibrium}

A detailed description of the equilibrium process of this model economy can be found in the technical appendix, which can be downloaded from http://www.ugr.es/ julianalbertodiaz/research/PEN65APP-K21.pdf.

\section{Calibration}

To calibrate our model economy, we choose 2014 as our calibration year. Then we choose the initial conditions and the parameter values that allow our model economy to replicate as closely as possible selected macroeconomic aggregates and ratios, distributional statistics, and institutional details of Spain in 2014.

More specifically, to characterize our model economy fully, we must choose the values of 5 initial conditions and 56 parameters. To choose the values of these 56 parameters, we need 56 equations which formalize our calibration targets. We determine the values of 36 of those parameters directly because they involve either a single parameter or a single parameter and our guesses for the values of aggregate capital and aggregate labor. To determine the values of the remaining 20 parameters, we solve a system of 20 non-linear equations. We describe these steps and our computational procedure in the on-line technical appendix which is available at http://www.ugr.es/ julianalbertodiaz/research/PEN65-APP-K21.pdf.

\section{Simulation}

We use our model economy to simulate four economies. In our benchmark model economy, which we label Model Economy Ben, we replicate the 2011 and 2013 Spanish pension system reforms with all their details. Specifically, we extend the number of years of earnings that we use to compute the pensions, we delay the retirement ages, and we apply the Pension Revaluation Index and the Sustainability Factor. In the remaining model economies, we continue to replicate the 2011 and 2013 Spanish pension system reforms but assume that part or all pensions are fully indexed with 
the Consumer Price Index (CPI). Specifically, in the first reformed model economy, which we label Model Economy Re1, we analyse a scenario in which only disability and minimum pensions are fully indexed with the CPI. In the second reformed model economy, which we label Model Economy Re2, we assume that all those pensions whose value is less than 40 percent of per-capita GDP are fully indexed with the CPI. Finally, in the third reformed model economy, which we label Model Economy Re3, we assume that all pensions in payments are revaluated with the CPI. All model economies have exactly the same initial conditions and share the demographic, educational, growth, inflation, and fiscal policy scenarios that we describe below.

The Demographic Scenario. The demographic scenario replicates the demographic projections for Spain for the period 2014-2064 estimated by the Instituto Nacional de Estadística (INE) in 2014. ${ }^{18}$ In Panel A of Figure 1 we plot the changes in the 65+ to 20-64 dependency ratio that result from this scenario. This ratio increases from 29.3 in 2014 to 78.4 in $2070^{19}$.

The Educational Scenario. The initial educational distribution of our model economies replicates the educational distribution of the Spanish population in 2014, as reported by the INE ${ }^{20}$. After 2014, we assume that the educational shares for the 20-year old entrants are 7.33 percent, 62.62, and 30.05 percent forever for drop-outs, high school graduates, and college graduates. Those shares are the educational shares of the most educated cohort ever in Spain, which corresponds to the 1980 to 1984 cohort. ${ }^{21}$ In Panel B of Figure 1 we plot the changes in the distribution of education shared by all model economies. The shares of high school drop-outs, high school graduates, and college graduates change from from 27.9, 53.0, and 19.1 percent in 2014 to $7.1,64.7$, and 28.2 percent in 2070.

The Growth Scenario. We assume that the labor productivity growth rate increases from 0 percent in 2014 to 1.5 percent in 2022, 0.2 percentage points per year. And after that year, this rate remains constant at that same value (see Panel C of Figure 1). The rationale for this choice is twofold. First, because, and as stated by Boldrin et al. (2010), labor productivity growth in Spain has almost disappeared after 1995. And second, because the Spanish average annual labor productivity growth rate between 1980 and 2012 was 1.5 percent, according to the OECD.

Note that in our model economy there are three sources of output growth: the changes in the labor-augmenting productivity factor, $\gamma_{t}$, the changes in the demographic and educational distributions, which are exogenous; and the changes in labor hours and savings brought about by the changes in the unemployment rate, prices, pensions, and consumption tax rates, which are endogenous. Thus, and between 2015 and 2070, these exogenous sequences and the endogenous

\footnotetext{
${ }^{18}$ These projections can be found at http://www.ine.es/inebaseDY N/propob30278/propob nlaces.htm.

${ }^{19}$ We project the distribution of households between 2065 and 2150 with a procedure that we describe in the on-line Technical Appendix.

${ }^{20}$ The INE reports the educational distribution of the population by five-year age groups. We smooth this distribution through the estimation of polynomial curves.

${ }^{21}$ Conde-Ruiz and González (2013) also use this educational scenario.
} 
responses result in average growth rate of output of 1.42 percent in our benchmark Model Economy Ben.

Figure 1: The Simulation Scenarios in All Model Economies
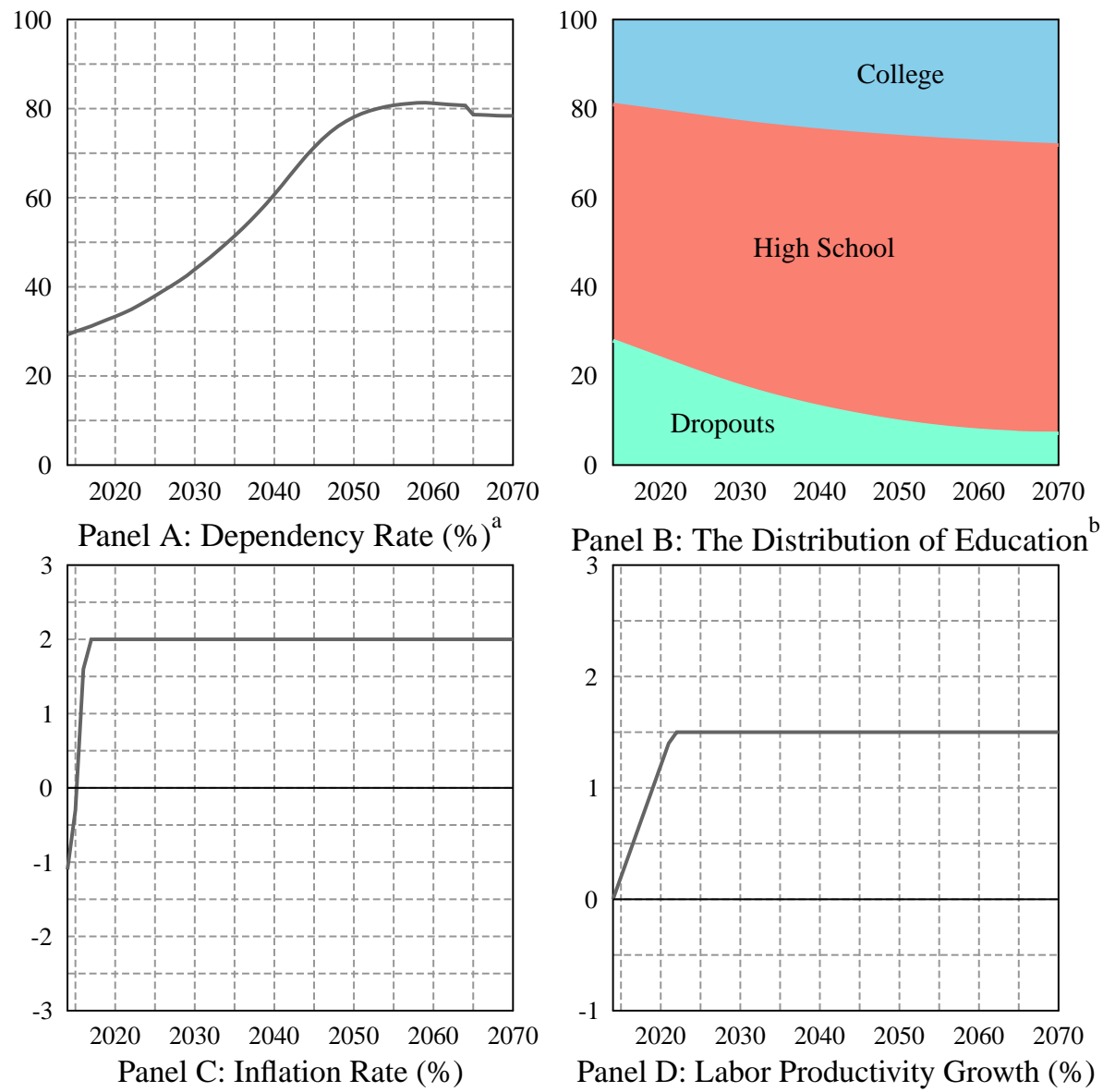

${ }^{a}$ This is the ratio between the number of households in the $65+$ age cohort and those in the $20-64$ age cohort. ${ }^{b}$ This is the distribution of education of the households in the 20-64 age cohort.

The Inflation Rate Scenario. The exogenous yearly inflation rates in our model economy for the 2014-16 period are $-1.1,-0.3$, and 1.6 per cent. Since the Spanish Government revaluated the pensions at a yearly 0.25 growth rate during those same years, the real Pension Revaluation Index was $1.35(=0.25-(-1.1)), 0.55(=0.25-(-0.3))$, and $-1.35(=0.25-1.6))$ percent respectively. After 2016, we assume that the inflation rate in our model economy is 2 percent because that is the inflation rate targeted by the European Central Bank (see Panel C of Figure 1). This inflation rate scenario implies that from 2017 the real value of the lower bound of the PRI is $-1.75(=0.25-2.00)$ percent thereafter and the real value of the upper bound of the PRI is 0.5 percent. Finally, we also assume that the CPI increases at a yearly rate of 2 percent.

The Fiscal Policy Scenario. Recall that the consolidated government and pension system budget 
constraint in our model economy is given in Expression (1) In that expression $G_{t}$ is exogenous and the remaining variables are endogenous. In all model economies the capital income tax rates and the parameters that determine the payroll tax function and the household income tax function are identical and they remain unchanged at their 2014 values. The consumption tax rates differ across the economies because we adjust them to finance the pensions once the pension reserve fund is exhausted. Every other variable in Expression (1) varies with time and differs across both economies because they are all endogenous.

Reform Announcement. We assume that all the reforms of Spanish pensions are announced and implemented at the beginning of 2018 .

Table 1: Simulation Results

\begin{tabular}{|c|c|c|c|c|c|c|c|c|c|}
\hline Model & Rev & Exp & $\overline{\mathrm{Bal}}$ & AvP & AvA & $\tau_{c}$ & $\mathrm{Y}$ & $\mathrm{K}$ & $\overline{\mathrm{L}}$ \\
\hline \multicolumn{10}{|c|}{2014} \\
\hline 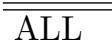 & 10.4 & $\overline{\overline{12.2}}$ & $\overline{-\overline{-1.8}}$ & $\mid 100.0$ & $\overline{c 63.2}$ & $\overline{20.4}$ & |100.0 & 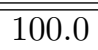 & 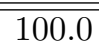 \\
\hline \multicolumn{10}{|c|}{2030} \\
\hline$\overline{\overline{\text { Ben }}}$ & 9.8 & 10.3 & -0.5 & $\mid 104.8$ & 66.2 & 21.4 & $\mid 141.4$ & 133.0 & 121.7 \\
\hline Re1 & 9.8 & 10.8 & -1.0 & 108.4 & 65.9 & 22.5 & 140.0 & 131.9 & 121.1 \\
\hline $\operatorname{Re} 2$ & 9.8 & 11.2 & -1.4 & 109.8 & 65.5 & 23.4 & 138.3 & 130.1 & 119.8 \\
\hline Re3 & 9.9 & 12.0 & -2.1 & 117.4 & 66.1 & 24.8 & 136.5 & 126.9 & 119.0 \\
\hline \multicolumn{10}{|c|}{2050} \\
\hline$\overline{B e n}$ & 9.1 & 11.3 & -2.2 & 1117.8 & 68.6 & 25.0 & 183.5 & 183.5 & 1111.0 \\
\hline $\operatorname{Re} 1$ & 9.0 & 12.3 & -3.3 & 127.4 & 68.7 & 27.2 & 180.8 & 178.7 & 111.4 \\
\hline $\operatorname{Re} 2$ & 9.2 & 13.3 & -4.1 & 129.0 & 67.8 & 28.9 & 175.9 & 173.8 & 108.3 \\
\hline Re3 & 9.2 & 15.8 & -6.6 & 156.0 & 69.2 & 33.9 & 173.6 & 167.9 & 108.6 \\
\hline \multicolumn{10}{|c|}{2070} \\
\hline$\overline{\overline{\text { Ben }}}$ & $\overline{99.2}$ & $\overline{99.3}$ & 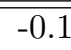 & $\mid 123.2$ & $\overline{c 67.9}$ & $\overline{20.6}$ & 219.8 & 215.3 & 100.5 \\
\hline Re1 & 8.9 & 9.6 & -0.7 & 139.1 & 69.5 & 21.9 & 221.8 & 211.5 & 104.7 \\
\hline $\operatorname{Re} 2$ & 9.3 & 11.9 & -2.4 & 148.3 & 67.7 & 25.7 & 209.6 & 203.4 & 97.4 \\
\hline $\operatorname{Re} 3$ & 9.3 & 14.9 & -5.6 & 188.0 & 69.1 & 31.7 & 205.6 & 195.7 & 97.0 \\
\hline
\end{tabular}

Rev: Pension revenues (\%GDP); Exp: Pension expenditures (\%GDP); Bal: Pension system balance (\%GDP); AvP: Average pension $(2014=100)$; AvA: Average retirement age; $\tau_{c}$ : Consumption tax rate needed to finance the pension system (\%). Y: Output index $(2014=100) ; K$ : Capital index (2014=100); L: Labor input index $(2014=100)$.

\section{Results}

We simulate our model economies using the demographic, educational, growth, fiscal, and inflation rate scenarios that we have described in Section 5, we report the main results of our simulations in Tables 1 and 2, and we illustrate the main results of our simulations in Figures 2 to 7.

The Sustainability Factor. Recall that the 2013 Reform of the Spanish pension system introduced the Sustainability Factor. This factor only affects new pensioners joining the system in 2019 onwards, and it operates in all our model economies. In Figure 2 we represent the values of the 
Figure 2: The Sustainability Factor

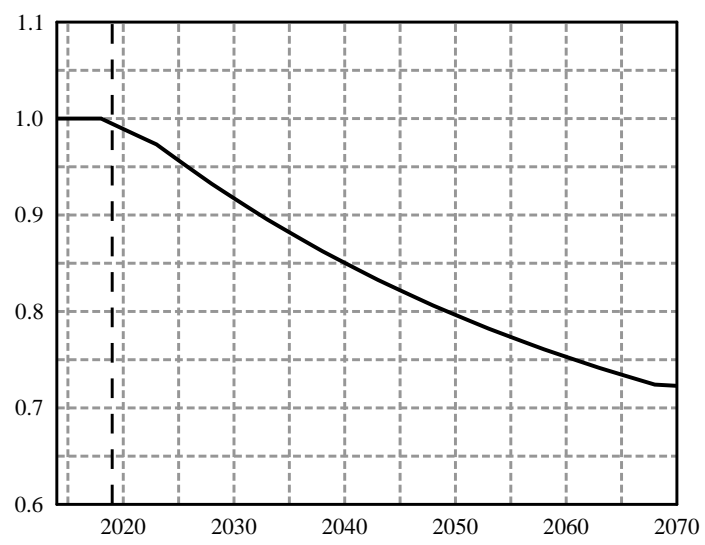

Source: Authors elaboration based on Spanish mortality rates in 2014.

Sustainability Factor that we have computed using the 2014 Spanish mortality tables. It turns out that, by 2070, the Sustainability Factor alone will have reduced the real yearly value of new Spanish pensions by 27.8 percentage points.

The Minimum, Maximum, and Average Pensions. In Figure 3 we plot the time series of minimum, maximum, and average pensions. Panels $\mathrm{A}$ and $\mathrm{B}$ of this figure show that both minimum and maximum pensions decrease by 53 percent in Model Economy Ben between 2014 and 2070, due to the PRI. Conversely, Panel $\mathrm{C}$ shows that the average pension increases by 23 during that same period, and this is because of two main reasons: first, due to the educational transition; and second, because labor productivity growth affects average pensions since pension rights track labor income and labor income tracks labor productivity. Panels D, E, and F show these same pensions as a proportion of output per capita, and the profiles are similar since the ratios plummet from 20, 141, and 42 percent in 2014 to 5, 30, 24 percent in 2070, respectively. Note also that the ratio of average pension to output per capita can be thought of as a measure of the adequacy or generosity of the pension system ${ }^{22}$, so that, all other things being constant, a decline in this ratio over time points to a fall in the generosity of public pensions, relative to output per capita. Thus, the projected reduction in this adequacy ratio is expected to contribute to improving public finances but it could also increase poverty risk among older people in the future.

Figure 3 also shows that the differences between the benchmark and the reformed model economies are large. The aforesaid reforms imply that minimum pension stays constant in real terms from 2018, and that the average pension grows by approximately 39, 48, and 88 percent between 2014 and 2070 in Model Economies Re1, Re2, and Re3 respectively. Consequently, and

\footnotetext{
${ }^{22}$ Another commonly used definition of pension adequacy is the ratio average pension to average labor earnings.
} 
Figure 3: The Minimum, Maximum, and Average Pensions
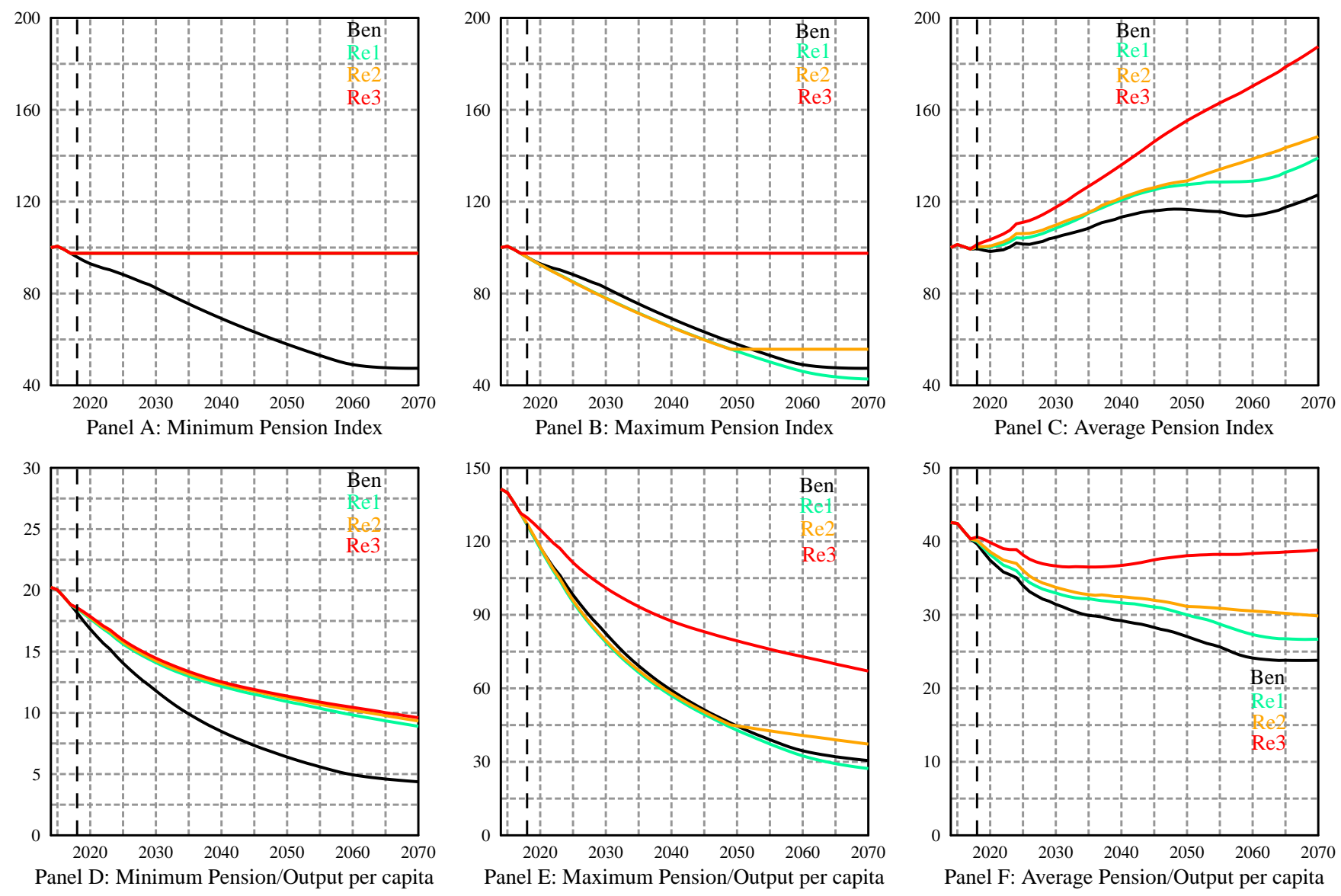

*As a percentage of output.

in terms of per capita output, Panel D shows that in 2070 the minimum pension is approximately 5 percentage points higher in the reformed economies than in Model Economy Ben, while Panel $\mathrm{F}$ shows that the average pension is 3,6 , and 15 percentage points higher. Finally, the maximum pension falls in all economies except in Model Economy Re3, where all the pensions are indexed to the CPI (see Panel B of Figure 3). Note also that the maximum pension remains constant after 2049 in Model Economy Re2, and this is because in that year this pension falls below 40 percent of per-capita output, mainly due to both the PRI and the per-capita output growth ${ }^{23}$.

Thus, returning to a full CPI indexation of part or all of Spanish pensions increases somewhat the generosity of the pension system, and this is particularly important for disabled households, since people with disabilities are at much higher risk of poverty and social exclusion than the general

\footnotetext{
${ }^{23}$ Note that the maximum disability pension remains constant from 2018 in Model Economy Re1, as all disability pensions are fully indexed with the CPI.
} 
population ${ }^{24}$. However, these reforms are far from eliminating the risk of pension inadequacy in the long run, particularly because such rules are also applied to minimum pensions. That is, indexing minimum pensions to prices instead of wages is problematic, as minimum pensions are tool to prevent the poverty of people in old age, as stated by Carone et al. (2016).

Figure 4: The Pension System Budget
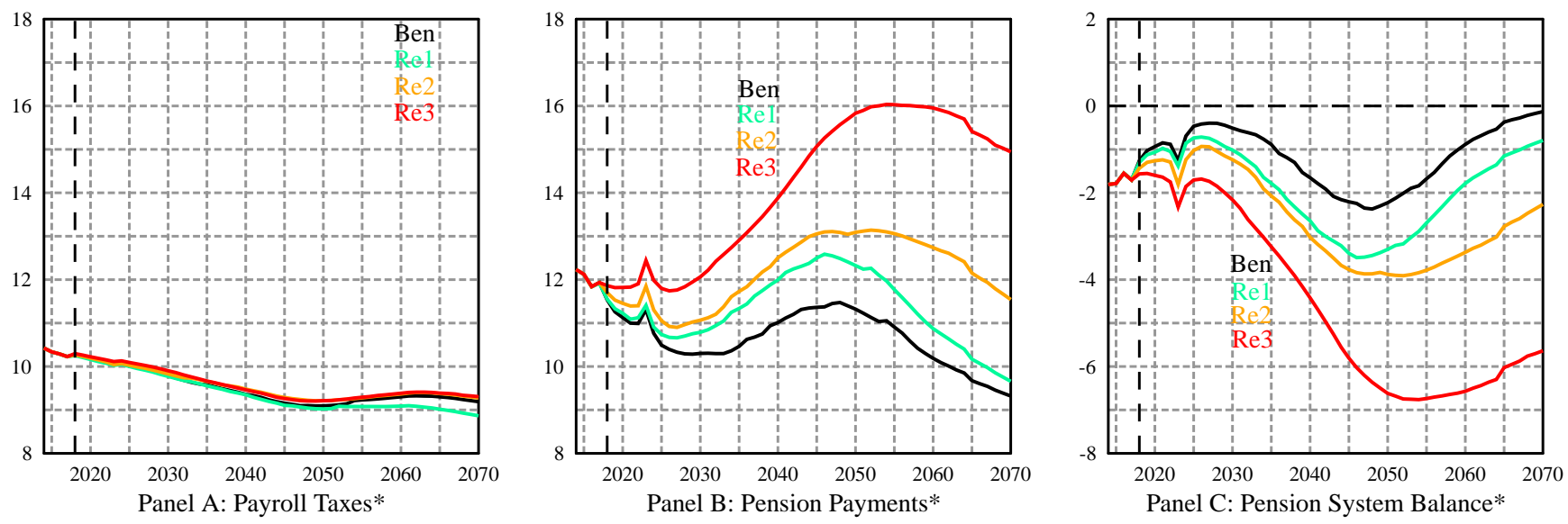

${ }^{*}$ As a percentage of output.

The Pension System. We plot the sequences of payroll tax collections, pension payments, and pension surpluses in Figure 4. Panel A shows that there is no significant variation in payroll taxes as a share of output. Moreover, this ratio decreases in all model economies due to two main reasons. First, because the educational transition increases the share of those workers who earn more than the maximum taxable earnings. And second, because the delay in retirement from the labor force also increases the share of workers exempt from the paying of payroll taxes ${ }^{25}$. This last reason is particularly important in the reformed economy Re1, as disability risk is covered by more generous pensions. Consequently, payroll taxes as a proportion of output is 0.5 points lower at 2070, in comparison to the other model economies (see second and sixth columns of Table 1.).

Panel B shows that the ratio of pension payments to output decreases in Model Economy Ben by around 3 percentage points between 2014 and 2070, from 12.2 percent to 9.3 percent. This happens because output grows at a higher rate than the sum of the growth rates of the average pension and of the number of pensions, and this is mostly because the PRI substantially reduces

\footnotetext{
${ }^{24}$ Note that the ratio of average pension to output per capita also decreases in Model Economy Re3, since an indexation rule that is lower than nominal output growth, as is the case with CPI indexation, reduces the pension benefit of an individual relative to output per capita as the latter increases.

${ }^{25}$ In principle, one would expect that the effective retirement age would not increase at the same pace as the legal retirement ages due to higher incidence of disability at older ages. Our results, however, show that in the long run the average retirement age is higher than the full entitlement retirement age in all model economies. This is because both the wage growth and the reduced pensions increase the opportunity cost of retiring.
} 
the growth rate of the average pension. Finally, Panel C of Figure 4 shows that in Model Economy Ben the pension deficit goes from 1.2 percent of output in 2018 to 2.4 percent of output in 2048, and this is mainly because the average growth rates of payroll taxes and pension expenditure for that same period are 1.3 and 1.75 percent. After that year, and mainly because most baby-boomers have already retired, the pension deficit to output ratio decreases to 0.1 percent in 2070 .

As expected, all these pension reforms increase pension expenditure. Specifically, the reforms would on average increase yearly pension expenditure by $0.64,1.46$, and 3.46 percentage points of output during the ensuing decades in Model Economies Re1, Re2, and Re3 respectively (see Panel B of Figure 4$)^{26}$. Therefore, the pension deficit to output ratio goes from 1.2 percent in 2018 , to 3.4, 3.9 and 6.9 percent in 2048 in Model Economies Re1, Re2, and Re3 (see Panel C of Figure 4). Note that these numbers are 1.0, 1.5, and 4.5 percentage points higher in comparison to the benchmark Model Economy Ben that same year.

Figure 5: The Consumption Tax Rate and the Real Pension Revaluation Index (\%)
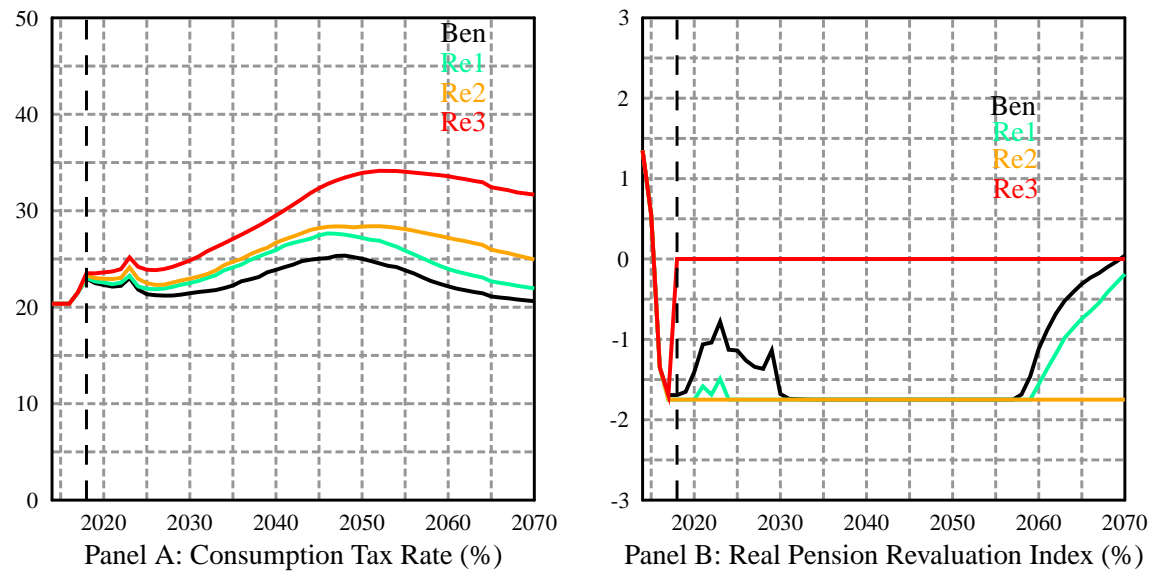

The Indexation of Pensions. In Panel B of Figure 5 we plot the PRI obtained in the Model Economy Ben. We find that the PRI is always negative between 2016 and 2070, and its accumulated value is -74.5 percent for that same period. Between 2019 and 2023, the PRI increases because pension expenditure growth decreases as the 2013 reforms are being phased in. After that year the PRI becomes increasingly negative because the baby boom cohorts start to retire. And during the period between 2030 and 2057, this index hits its lower bound, because the pension deficit increases (see Panel C of Figure 4). Finally, and once the old-age dependency ratio stabilizes (see Panel A of Figure 1), the real PRI increases and it becomes positive.

The reformed model economies Re1 and Re2 further reduce the real PRI, as they increase pension expenditure. Thus, in the case of Model Economy Re2 where every pension whose value

\footnotetext{
${ }^{26}$ Note in Model Economy Re3 the profile of the pension expenditure to output ratio closely resembles the profile of the old-age dependency ratio.
} 
is less than 40 percent of per-capita output is fully indexed with the CPI, the PRI is located at its lower limit for every year between 2018 and 2070. In contrast, Model Economy Re3 assumes that all pensions in payments are revaluated according with the CPI, so that the real yearly revaluation rate of pensions is null in this model economy (see Panel B of Figure 5).

Fiscal Consequences. Recall that we assume that, once that the Pension Reserve Fund is depleted, the government increases the consumption tax rate, $\tau_{c t}$, to collect additional fiscal revenues in order to balance the pension system budget ${ }^{27}$. Thus, the consumption tax rate necessary to finance Spanish pensions under Model Economy Ben increases up to 25.0 percent in 2050 and then decreases to 20.6 percent in 2070 as the pension deficit almost disappears (see Panel A of Figure 5).

The aforesaid pension reforms would entail an increase of the consumption tax rate. Specifically, this tax is 27.2, 28.4, and 33.9 percent in Model Economies Re1, Re2, and Re3 in 2050, and these numbers are $2.2,3.4$, and 8.9 percentage points higher in comparison to that same number in Model Economy Ben that same year. Note that increasing indirect taxes in order to pay for higher pensions affects the population as a whole, including pensioners as well as workers ${ }^{28}$. Thus, even though the value of pensions increases in all the reformed model economies, retirees would see their adjusted pensions increased by a small amount through the impact of higher indirect taxes ${ }^{29}$. And since there is no significant variation in wage rates across all model economies, workers face a reduction in their adjusted earnings.

Capital, Labor, and Output. In Figure 6 we plot the time series of factor inputs and output. We find that all pension reforms reduce the incentives to save. Panel B of Figure 6 shows that capital stock is 2.6, 5.1, and 9.1 percent lower in 2070 in Model Economy Re1, Re2, and Re3, and this is mainly because a large share of the population takes advantage of the more generous pensions and reduces its savings for old age.

Total labor input also decreases in Model Economies Re2 and Re3 by 2.5 and 3.6 percent in 2070 (see Panel C of Figure 6). To gain some intuition about where this drop in total effective hours comes from, Panels D, E and F show the dynamics of its components. Thus, Panel F shows that the decrease in total labor is mainly accounted for by the reduced average hours worked due to the higher consumption tax rates ${ }^{30}$. Consequently, Panel A shows that in 2070 output is 3.7 and 6.9 percentage points lower in Model Economies Re2 and Re3, so that these pension reforms reduce the yearly average growth rate of output between 2018 and 2070 from 1.42 percent in Model Economy Ben to 1.35 and 1.28 percent in the reformed economies Re2 and Re3.

\footnotetext{
${ }^{27}$ Our simulations show that the Pension Reserve Fund is depleted in 2017.

${ }^{28}$ Note also that the pension reform Re3 is equivalent to increasing taxes to allow for an increase of 2 percent in pensions, at the time it is maintained the PRI.

${ }^{29}$ We refer here to adjusted pensions and earnings, as these variables divided by the term $\left(1+\tau_{c t}\right)$.

${ }^{30}$ Panel E shows that there is an initial increase in the number of workers in all model economies due to the drop in the unemployment rate that follows from the output growth. After 2030, however, the number of workers decreases mainly due to the aging of the Spanish population.
} 
Figure 6: Main Aggregates
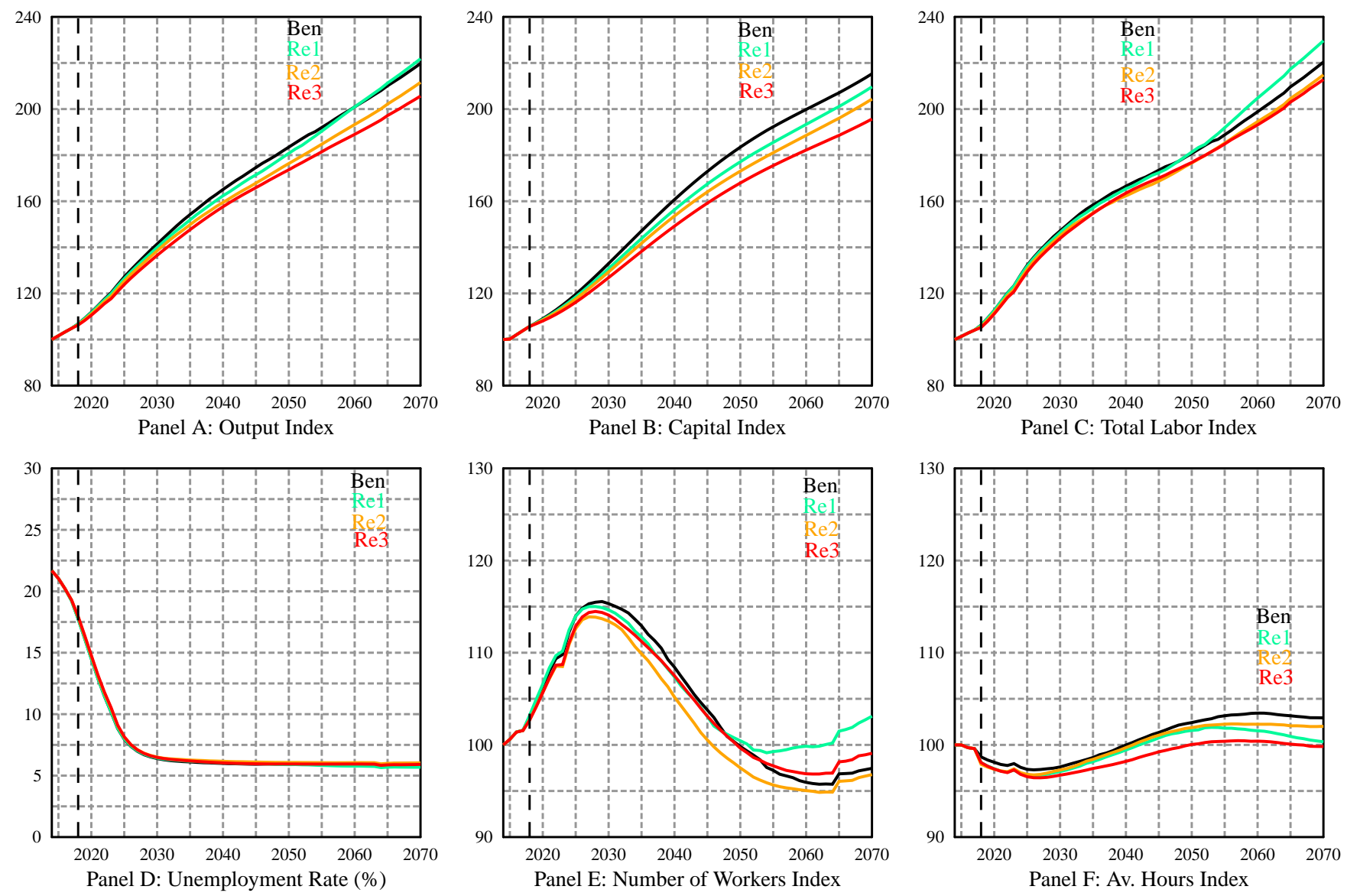

Total labour input, however, increases in Model Economy Re1. This is because the lower average hours worked due to the higher consumption tax rates is compensated for by the increase in the number of workers that follows from the delay in their retirement ages (see Panel E of Figure 6). Specifically, workers stay longer in the labour market because disability risk is covered by more generous pensions, since only minimum and disability pensions are revaluated with the CPI. Consequently, this reform brings a not significant variation in output in comparison to Model Economy Ben.

The Inequality of Pensions. In Panels A and B of Figure 7 we represent the share of the retirees and disabled who collect the minimum and maximum pensions. We find that in 2070 in Model Economy Ben the share of those collecting the minimum pension is lower in comparison to the reformed economies. And the opposite holds for those retirees collecting the maximum retirement pension that same year. To be specific, in 2070 in Model Economy Ben, 4.9 and 54.1 percent of retirees and disabled collect the minimum and maximum pensions respectively. In Model Economy 
Table 2: The Distribution of Pensions in 2070

\begin{tabular}{l|c|rrr|rrrrr|rrr}
\hline \hline & & \multicolumn{6}{|c|}{ Bottom Tail } & \multicolumn{4}{|c|}{ Quintiles } & \multicolumn{3}{|c}{ Top Tail } \\
\hline \hline & Gini & 1 & $1-5$ & $5-10$ & 1st & 2nd & 3rd & 4th & 5 th & $10-5$ & $5-1$ & 1 \\
\hline \hline Ben & 0.185 & 0.2 & 0.8 & 1.7 & 7.7 & 16.8 & 24.3 & 25.6 & 25.6 & 6.4 & 5.1 & 1.3 \\
Re1 & 0.203 & 0.4 & 1.8 & 2.2 & 8.8 & 14.2 & 22.8 & 27.0 & 27.0 & 6.8 & 5.4 & 1.4 \\
Re2 & 0.185 & 0.3 & 1.2 & 1.6 & 8.1 & 16.0 & 24.1 & 25.8 & 25.8 & 6.5 & 5.2 & 1.3 \\
Re3 & 0.296 & 0.2 & 1.0 & 1.3 & 6.1 & 12.1 & 19.2 & 27.7 & 34.9 & 8.7 & 7.0 & 1.7 \\
\hline \hline
\end{tabular}

Figure 7: Households Collecting Minimum and Maximum Pensions and the Gini Index of Pensions
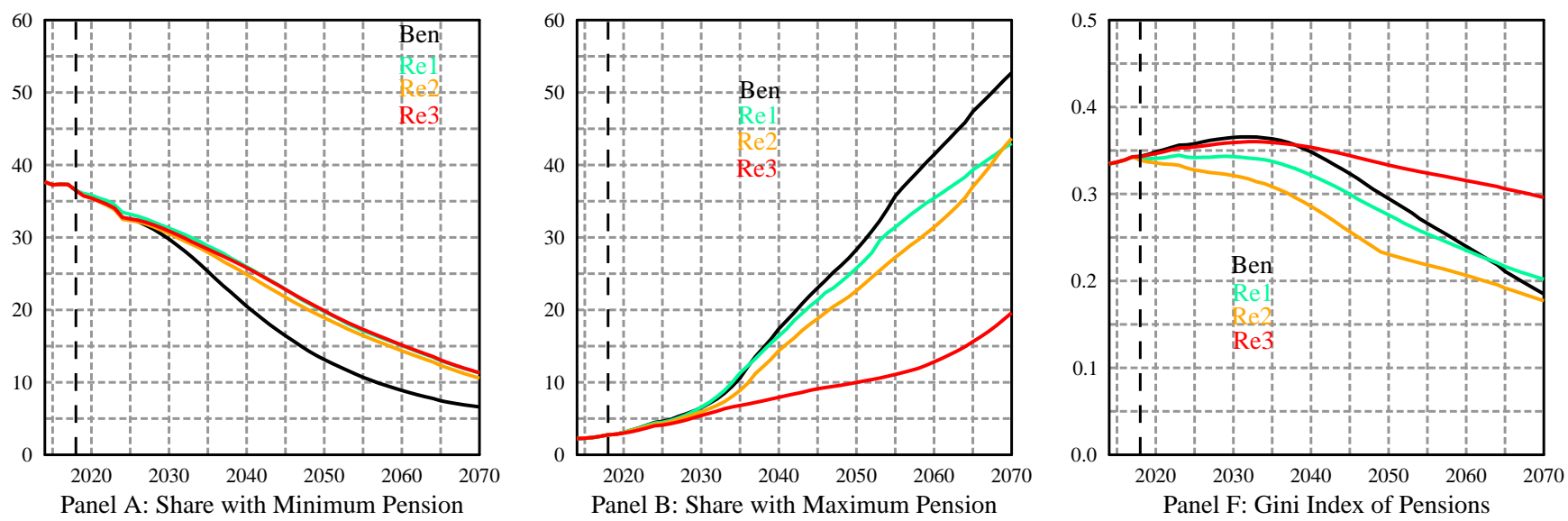

Re1, these figures are 11.3 and 43.0 percent, in Model Economy Re2 these numbers are 10.5 and 43.7 percent, and in Model Economy Re3 they are 9.8 and 22.8 percent. The reductions in the minimum and maximum pensions brought about by the PRI in Model Economy Ben is mainly behind these results.

Finally, Panel C of Figure 7 shows the sequences of the Gini indexes of pensions, and Table 2 reports selected points of the Lorenz curves of the distributions of pensions in 2070. We find that if all pensions are revaluated according with the CPI, they become more unequally distributed, since the Gini index in 2070 increases from 0.296 in Model Economy Ben to 0.334 in Model Economy Re3. And as we report in Table 2, most of these changes are accounted for by decreases in the share of pensions collected by the households in the bottom tail of the pensions distribution. On the other hand, pensions are more equally distributed under Model Economies Re1 and Re2 since these reforms only revalue lower-value pensions with the CPI.

Overall Assestment. The aforesaid pension reforms essentially imply trading off higher pensions against the higher taxes that are needed to finance them. On average, the CPI indexation for part or all Spanish pensions would entail that, on average, annual pension expenditure would be 
0.64, 1.46, and 3.46 percentage points of output higher up to 2070. To obtain additional revenues, the Spanish government has a limited menu of tax increases, with changes in indirect taxes being the preferred option among experts proposing alternatives for reforming the Spanish Tax System, mainly for reasons of efficiency. Our results show, however, that consumption tax rates should be increased on average by $1.5,2.9$, and 6.9 percentage points respectively during that same period. Moreover, such increases could reduce total hours of work and, consequently, the growth rate of output. As we show below, in social welfare terms, these reforms bring about very different welfare outcomes.

\section{$7 \quad$ Welfare}

Figure 8: The Welfare Cost of the Reforms: Alive (CEV, \%)*
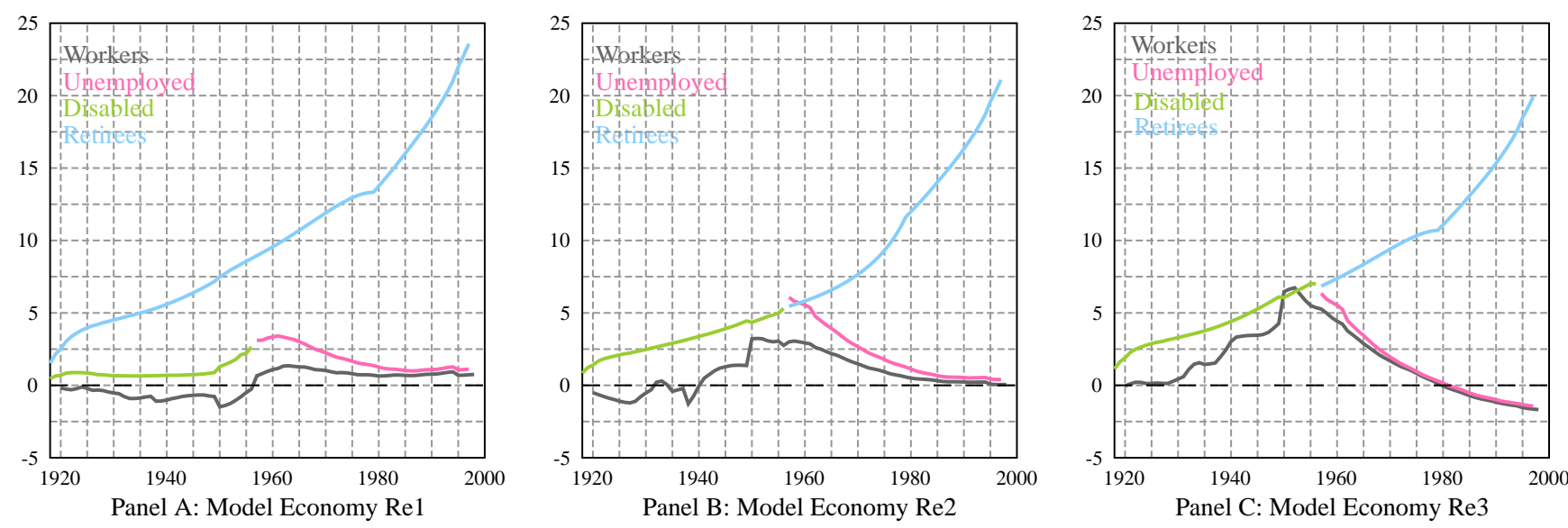

${ }^{*}$ The three panels of this figure report the welfare gains of the household-types organized by year of birth.

To quantify the welfare effects of the return to full price indexation of Spanish pensions, we use a consumption equivalent variation measure (CEV). Specifically, we compute the percentage change in a household's yearly consumption that equates its expected lifetime utility in Model Economies Ben and a given pension reform. We start our computations in 2018, which is the year when the reforms are announced and implemented, and we compute the CEV measure for all the households who are alive that year, and for those who enter to the model economies between 2019 and 2070. Since we assume that new-entrants are 20 years-old, these cohorts of households would have been born between 1999 and 2050. In Figure 8 we report the results of our welfare comparisons for the households who are alive in 2018 when the reforms are implemented. Panel A of Figure 9 shows the welfare results for the households born between 1918 and 2050. Finally, Panel B of Figure 9 shows the aggregate welfare gains ${ }^{31}$.

\footnotetext{
${ }^{31}$ To measure the yearly welfare gains we add the consumption equivalent variations of every household who is
} 
Alive. Figure 8 shows the average welfare gains of the households alive in 2018 when the pension reforms are implemented. These households were born between 1918 and 1998 and some of the youngest households will survive until 2098. We find that all disabled households gain in all reformed economies because they receive a higher disability pension for longer, and that their welfare gains are larger in Model Economy Re1. This is because under this reform all disability pensions are fully indexed with the CPI, as in Model Economy Re3. However, and unlike Model Economy Re3, this reform limits the tax increases needed to finance the pension system deficits. The gains in Model Economy Re1 are increasing and they range from 1.5 percent of consumption for the disabled households born in 1918 to 23.6 percent for those disabled who were born in 1997.

All retirees are better off in the Model Economy Re3; only low income retirees are better off in Model Economy Re2, and only those retirees who collect minimum pensions are better off in Model Economy Re1. Panel C of Figure 8 shows that welfare gains are higher in the Model Economy Re3, as this reform fully indexes all retirement pensions with the CPI. In this last economy, these gains range from 1.1 percent for those born in 1918 to 7.0 percent of lifetime consumption for those born in 1956. Note also that welfare gains decrease with age because old retired households will benefit from higher pensions for a shorter time period.

Older workers, as in the case of retirees, also prefer Model Economy Re3, where their welfare gains increase until 6.7 percent of lifetime consumption for those born in 1953. Thereafter, welfare gains decrease and become welfare losses that reach 1.7 percent of lifetime consumption for those born in 1998, so that younger workers like better Model Economy Re1. Put differently, and despite their higher future pensions brought about by the Model Economy Re3, younger workers lose with this reform because they will face higher consumption taxes during the rest of their lifetimes. Finally, most of unemployed households are better off under Model Economy Re2. This is because these households face some periods of unemployment, so that they have to make do with a reduced future retirement pension.

Newborns. In Panel A of Figure 9 we report the average individual welfare gains of the household types. This figure also shows that newborns like better Model Economy Re1, since their average welfare gains range from 0.7 percent to 3.0 percent. Newborns are willing to pay more taxes to the point where these higher tax revenues increase those pensions directed to reduce both poverty and disability risk. On the other hand, the return to the full price indexation of all public pensions entails welfare looses that exceed 2 percent of lifetime consumption.

Aggregate Welfare Gains. In Panel B of Figure 9 we report the aggregate welfare gains. To compute these sequences, we consider both households alive in 2018, and those cohorts born between 1999

alive that year and we express them as a percentage of aggregate consumption that year. For instance, suppose an economy where household $a$ consumes 10 , household $b$ consumes 5 , and that their consumption equivalent variations are 7 and and 5 percent, when we consider the reformed economy Rei. Then, the total consumption needed to make them indifferent between the benchmark Model Economy Ben and the reformed Model Economy Re $i$ is 0.95 $(=10 \times 0.07+5 \times 0.05)$, and the aggregate welfare gains are 6.3 percent $(=0.95 / 15)$. 
Figure 9: The Average and Aggregate Welfare Gains of the Reforms (\%)
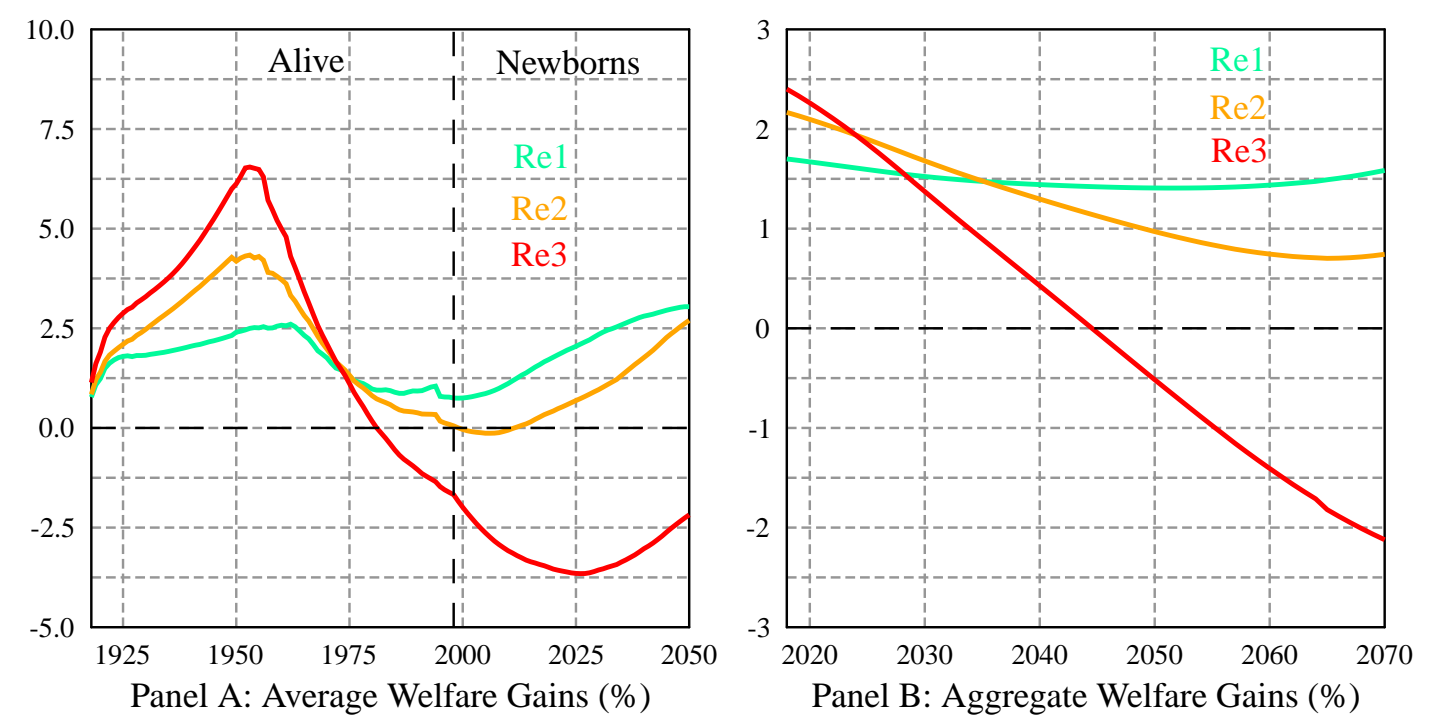

and $2050^{32}$. We find that the reformed Model Economy Re1 produces an average aggregate welfare gain of 1.49 percent of total consumption between 2018 and 2070. For the remaining two reformed model economies, these numbers are 1.25 and 0.07 percent for that same period. Nevertheless, we also find that most of the households alive at the time of these pension reforms prefer the return to a price indexation rule of all Spanish pensions, since this reform brings about sizeable aggregate welfare gains equivalent to 2.9 percent of aggregate consumption.

\section{Sensitivity Analysis}

In this section we analyze the sensitivity of our findings to our assumptions regarding the labour augmenting growth rate and the inflation rate scenarios. In Table 3 we report the values of some of the main macroeconomic variables in 2070 under these scenarios, and in Figure 10 we compare the welfare costs of the reforms.

\subsection{Growth Rate Scenario.}

Our Baseline scenario assumed that the labor productivity growth rate increases from 0 percent in 2014 to 1.5 percent in 2022, and it remains constant at this same value thereafter. To check the robustness of our findings, we simulate all model economies again, assuming that the annual

\footnotetext{
${ }^{32}$ Recall that since we assume that new-entrants are 20 years-old, those born at 2050 will enter to the economy at 2070 .
} 
Table 3: Main Aggregates and Ratios in 2070

\begin{tabular}{l|rrr|lll|lll}
\hline \hline Model & Rev & Exp & Bal & AvP & AvA & $\tau_{c}$ & Y & K & L \\
\hline \hline \multicolumn{10}{c}{ Baseline Scenario } \\
\hline \hline Ben & 9.2 & 9.3 & -0.1 & 123.2 & 67.9 & 20.6 & 219.8 & 215.3 & 100.5 \\
Re1 & 8.9 & 9.6 & -0.7 & 139.1 & 69.4 & 21.9 & 221.8 & 211.5 & 104.7 \\
Re2 & 9.3 & 11.9 & -2.4 & 148.3 & 67.7 & 25.7 & 209.6 & 203.4 & 97.4 \\
Re3 & 9.3 & 14.9 & -5.6 & 188.0 & 69.2 & 31.7 & 205.6 & 195.7 & 97.0 \\
\hline \hline \multicolumn{10}{c}{ Low Growth Scenario } \\
\hline \hline Ben & 9.3 & 10.6 & -1.3 & 101.7 & 67.2 & 23.1 & 161.5 & 174.7 & 101.4 \\
Re1 & 9.1 & 12.1 & -3.0 & 102.3 & 68.2 & 26.5 & 161.1 & 164.9 & 103.4 \\
Re2 & 9.4 & 14.8 & -5.4 & 130.0 & 66.8 & 31.3 & 151.1 & 157.1 & 95.7 \\
Re3 & 9.5 & 19.2 & -9.7 & 169.5 & 68.3 & 39.6 & 147.7 & 151.7 & 97.2 \\
\hline \hline & \multicolumn{10}{c}{ Low Inflation Scenario } \\
\hline \hline Ben & 9.2 & 11.6 & -2.4 & 150.0 & 68.5 & 25.1 & 214.1 & 211.0 & 99.9 \\
Re1 & 9.2 & 12.6 & -3.3 & 160.4 & 68.7 & 27.3 & 211.6 & 203.7 & 98.6 \\
Re2 & 9.3 & 13.0 & -3.7 & 162.0 & 67.9 & 27.9 & 208.4 & 201.4 & 97.0 \\
Re3 & 9.3 & 14.9 & -5.7 & 188.6 & 69.2 & 31.7 & 205.8 & 197.3 & 98.6 \\
\hline \hline
\end{tabular}

Rev: Pension revenues (\%GDP); Exp: Pension expenditures (\%GDP); Bal: Pension system balance (\%GDP); AvP: Average pension $(2014=100)$; AvA: Average retirement age; $\tau_{c}$ : Consumption tax rate needed to finance the pension system (\%). Y: Output index $(2014=100) ; K$ : Capital index $(2014=100) ; L$ : Labor input index $(2014=100)$.

growth rate of labor productivity is only 0.75 percent from 2018 onwards.

Note that a drop in the labor productivity growth rate translates into decreases in wages and, therefore, in the value of future pensions, which depend on the wages received during the last part of the working lifetime. However, since both earnings included in the Regulatory Base and current pensions do not adjust with the rate of wage growth in all model economies, such a decrease in productivity growth gives rise to increases in the average pension to output per capita ratio, and, consequently, in the generosity of the system and in pension payments as a share of output.

The second block of Table 3 shows that pension expenditure in 2070 increases in all model economies, becoming 10.6, 12.1, 14.8 and 19.2 percent of output, respectively. This block also shows that there is no significant variation in the payroll taxes to output ratio, so that pension system deficits in 2070 increase to $1.3,3.0,5.4$ and 9.7 percent of output, respectively (see fourth column second block of Table 3). Hence, the consumption tax rates needed to finance these deficits are 23.1 26.5, 31.3 and 39.6 percent that same year. Finally, Panel B of Figure 10 shows that the profile of welfare gains and losses is similar to that obtained in the Baseline simulations, as shown in Panel A of that same figure. However, older households gain more, in comparison to the Baseline simulations, because the pension reforms increase the generosity of the pension system further, and, conversely, the losses (gains) for newborns are also higher (lower) since the tax increases required to finance pension expenditure are also higher.

In conclusion, although a slower pace for productivity growth reduces the growth of the average 
pension, it results in a higher generosity of the pension system, so that pension expenditure to output increases. Consequently, a lower labor productivity growth exacerbates the sustainability problems of Spanish Pension System, brought about by these pension reforms.

\subsection{Inflation Rate Scenario.}

Our Baseline scenario also assumes that both the GDP deflactor and the CPI increases an annual rate of 2 percent from 2017 onwards. As a final robustness check, we again simulate all model economies under a scenario where both variables growth to an annual rate of 1 percent from 2017 onwards. Note that this new scenario changes the lower bound of the PRI in real terms, since in this case this bound is now -0.75 percent $^{33}$. Moreover, the change in the inflation scenario does not affect Model Economy Re3, since this pension reform eliminates the PRI.

Our main findings under this low-inflation scenario are the following: In Model Economy Ben, the average pension increases by 50 percent between 2014 and 2070, rather than 23 percent for that same period in our Baseline scenario ${ }^{34}$. Consequently, the increases in the average pension due to the pension reforms are lower in this case, since these increases in 2070 are reduced from 12.9, 20.4, and 52.5 percent in the Baseline scenario to $6.8,8.0$, and 25.7 percent in this low-inflation scenario (see first and third block of Table 3). Thus, these pension reforms increase now the pension deficit by $0.9,1.3$, and 3.3 percentage points of output in 2070 , and the consumption tax rate increase in $2.2,2.8$, and 6.6 percentage points that same year. Finally, welfare gain and losses are lower because the lower increases in pensions and tax rates (see Panel $\mathrm{C}$ of Figure 10).

\footnotetext{
${ }^{33}$ The law establishes a minimum increase in nominal pensions of 0.25 percent. Therefore, in our baseline scenario, the lower bound of the PRI in real terms was -1.75 percent $(=0.25-2)$, while in the low-inflation scenario it is -0.75 percent $(=0.25-1)$.

${ }^{34}$ The average pension increases by more in Model Economy Ben under the low-inflation scenario because of the higher lower bound for the PRI.
} 
Figure 10: The Welfare Cost of the Reforms (CEV, \%)*
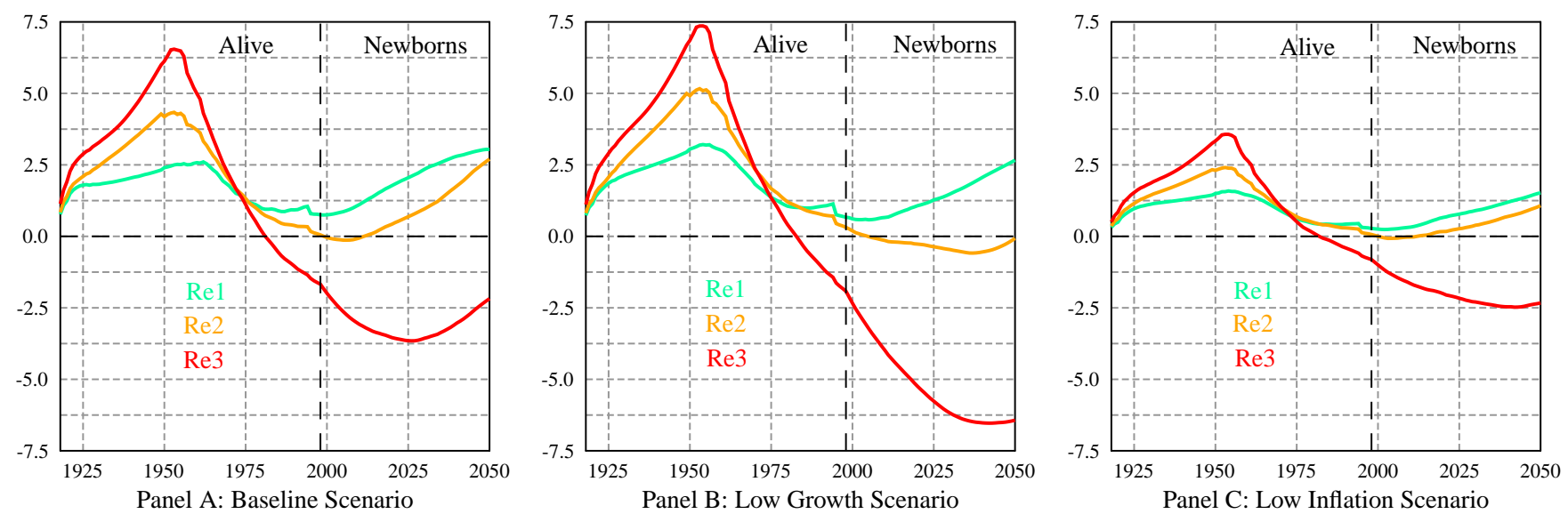

${ }^{*}$ The three panels of this figure report the welfare gains of households organized by year of birth.

\section{Conclusions}

In this article, we analyze the fiscal and welfare consequences of implementing a full price indexation for part or all Spanish pensions. These reforms increase pensions, pension adequacy and, consequently, pension expenditures and the pension deficit expected during the ensuing decades. Thus, the government would be forced to obtain additional revenues, either by increasing payroll taxes, or by increasing other taxes to pay for pension expenditure. And our results also show that higher pensions and higher indirect tax rates could entail labor supply and physical capital reductions.

On the other hand, our welfare results show that it would be desirable to move to a scenario in which only disability and minimum pensions were fully indexed with the CPI, since this rule would entail welfare gains for both most of the households alive at the moment this policy change, and also for future cohorts. However, although this pension reform would increase somewhat the generosity of the system, it is far from eliminating the risk of pension inadequacy over time especially because CPI indexation is applied to the minimum pension. That is, the indexation of minimum pensions to prices is problematic, as minimum pensions are an implement to prevent the poverty of people in old age.

We think that the current Spanish pension system should be overhauled and replaced by a system that combines targeted minimum pensions, fully contributive pay-as-you-go pensions, and mandatory individual retirement accounts. Specifically, the system could provide focused and reduced minimum pensions that guarantee a minimum level of income for the elderly. This type of pension, granted by nature of assistance, could be subject to the fulfilment of a series of requirements 
such as the income and the wealth of the beneficiaries. Regarding the second pillar, this reform could reduce the contributory rate by half, and it could also implement a system of defined contribution notional accounts, where the retirement pension would be determined by the annuity corresponding to contributions made during the working life and life expectancy at the time of retirement. Finally, the third pillar would be that provided by the insurance sector, and the system would impose on every worker the obligation to make monthly contributions to an individual capitalization account ${ }^{35}$.

The introduction of complementary private-pension pillars supports retirement incomes, through a higher accumulation of non-public pension rights, and provides a buffer against adverse shocks by diversifying pensioners' sources of income. Moreover, the reform that has just been briefly described has a series of advantages in relation to the system that currently prevails in Spain. First, the multiplicity of sources of income introduced by this reform has the advantage that they combine the low cost of insurance against the longevity risks offered by the pay-as-you-go systems, with the possibilities of geographic diversification of the investments offered by the capitalization systems. Second, this mixed system protects pensions from local economic cycles and the effects of these cycles on fiscal policy. Third, mixed systems encourage individual responsibility for pensions and retirement savings. And fourth, the lower payroll tax rates should foster tax collections and discourage the submerged economy. However, we believe that this type of pension reform should be put into place sufficiently early because the build-up of supplementary savings takes time.

\section{References}

[1] Argandoña A., J. Díaz-Giménez, J. Díaz-Saavedra, and B. Álvarez, (2013). El Reparto y la Capitalización en las Pensiones Españolas. Fundación Edad y Vida.

[2] Boldrin M., J. Conde-Ruiz, and J. Díaz-Giménez, 2010. Eppur si Muove! Spain: Growing Without a Model. FEDEA, Documento de Trabajo 2010/12.

[3] Carone G., P. Eckefeldt, L. Giamboni, V. Laine, and S. P. Summier, (2016). Pension Reforms in the EU since the Early 2000's: Achievements and Challenges Ahead. Directorate-General for Economic and Financial Affairs, European Commision.

[4] Chłoń-Domińczak A., (2018). Impact of changes in multi-pillar pension systems in CEE countries on individual pension wealth. Journal of Pension Economics and Finance, 17(01), 110120.

[5] Conde-Ruiz J. I., and C. I. González, (2013). Reforma de Pensiones 2011 en España. Hacienda Pública Española, IEF, 204(1), 9-44.

[6] De La Fuente A., and R. Doménech, (2013). The Financial Impact of Spanish Pension Reform: A Quick Estimate. Journal of Pension Economics and Finance, 12(01), 111-137.

\footnotetext{
${ }^{35}$ In Argandoña et al. (2013) we offer a preliminary simulation of this reform.
} 
[7] De La Fuente A., M. A. García Díaz, and A. R. Sánchez-Martín, (2018). La salud financiera del sistema público de pensiones español: proyecciones de largo plazo y factores de riesgo. FEDEA, Documento de Trabajo 2018/03.

[8] Díaz-Giménez J., and J. Díaz-Saavedra, (2017). The Future of Spanish Pensions. Journal of Pension Economics and Finance, 16(02), 233-265.

[9] European-Commission (2015). The 2015 Aging Report. Economic and budgetary projections for the 28 EU Member States (2013-2060). European Economy 3/2015.

[10] Grech A., (2005). Evaluatiog the Possible Impact of Pension Reforms on Elderly Poverty in Europe. Social Policy and Administration, 49, 68-87.

[11] Hernández de Cos P., J. F. Jimeno, and R. Ramos, (2017). The Spanish Public Pension System: Current Situation, Challenges, and Reform Alternatives. Banco de España, Documentos Ocasionales 1701.

[12] Holzmann R., and R. Hinz, (2005). Old-age Income Support in the 21st Century: An International Perspective on Pension Systems and Reform. World Bank.

[13] Humblet M., and R. Silva, (2002). Standards for the XXIst Century: Social Security. International Labour Office.

[14] Moral-Arce I., (2013). Aplicación de Factores de Sostenibilidad en el Sistema de Pensiones Español: Previsiones Para el Período 2012-2050. Instituto de Estudios Fiscales, P.T. 4/2013.

[15] Patxot C., M. Solé, and G. Souto, (2017). Should Pensions Be Redistributive? The Impact of Spanish Reforms on the Systems Sustainability and Adequacy. FEDEA, Documento de Trabajo $2017 / 02$.

[16] Sánchez-Martín A. R., (2017). Proyecciones Financieras y de Bienestar del Sistema Español de Pensiones: Resultados de Simulación. FEDEA, Documento de Trabajo 2017/15. 